\title{
Residential Mobility Behaviour amongst Households within Enugu Metropolis: does a change in household
} income matter?

\author{
Ehiemere, Nnamdi D \& Professor Ogbuefi, Joseph U. \\ Department of Estate Management, Faculty of Environmental Studies, University of Nigeria Enugu Campus
}

\begin{abstract}
Residential mobility behaviour amongst urban households is indicative of households' response to the need to optimize housing consumption. Social and economic considerations play a significant role and can either encourage or inhibit residential mobility. This research investigated the influence of variations in household income on household residential mobility behaviour in Enugu metropolis between 2007 and 2017. Survey research design was adopted and a sample of 865 households was randomly drawn from the three municipalities which make up Enugu metropolis. Observation checklists were used to collect data on housing conditions while questionnaires were used to elicit responses from households on their demographic data and residential mobility behaviour. Descriptive statistics were used to summarize household demographic data and analyse household residential mobility behaviour. Findings revealed that changes in household income, though negligible for the majority, translated to an $8 \%$ increase in households' demand for flats. Consequently, variations in household income affected the ability of households to optimize housing consumption.
\end{abstract}

\section{INTRODUCTION}

$\mathrm{H}$ ousehold residential mobility behaviour is one of the drivers of land use dynamics and the evolving spatial patterns within a sprawling city like Enugu metropolis. In order to harness the socio-economic opportunities provided by urban centres, as well as optimize housing consumption, households may exhibit certain residential mobility behaviour. This may be between tenures (renter to owner) or within tenures (owner to owner, renter to renter). Residential mobility within urban space, though considered a natural course in the life cycle of urban dwellers, significantly contributes to the spatial character of urban space. Human life events such as change in marital status, family size expansion, aging process, health challenges and changes in household income- to mention a few, are some reasons why households change residences within the urban area (De Groot, Mulder, Das, \& Manting, 2011). Inherent in these factors are push and pull pressures which households may respond to through residential mobility behaviour. Enugu metropolis, like most cities in Nigeria, has a rental dominated housing market (NBS, 2017) and a largely youthful population which may serve as triggers for rapid household residential mobility behaviour when compared to a predominantly aging population in an owner/occupier dominated housing market
(Viola and Laferrere, 2012; Hamizah, Abdul, Nurwati and Kausar, 2015).

Housing choices and residential mobility behaviour are largely influenced by household income (Shawal \& Ferdous, 2014) as changes in household income have been proven to have a significant influence on household residential mobility behaviour (Hamizah, Abdul, Nurwati and Kausar, 2015). Optimization of housing consumption amongst households may involve some trade-offs between advantages conferred on households by current housing and the perceived potential benefits in proposed housing options, albeit dependent on household income. Since optimization of housing consumption by households through residential mobility is largely dependent on household income, the aim of this research is to determine the influence of variations in household income on household residential mobility behaviour in Enugu metropolis between 2007 and 2017. Some research questions raised are: What is the demographic character of households in Enugu metropolis? What type of changes have occurred to the demographic character of households within Enugu metropolis? Do households within Enugu metropolis optimize their housing consumption in a rental dominated housing market if they have the financial means? How responsive to changes in household income is residential mobility behaviour within Enugu metropolis?

\section{LITERATURE REVIEW}

\subsection{Concept of Residential Mobility}

Residential mobility can be conceptualized from a wide range of perspectives. It could be viewed from the housing tenure perspective whereby a household transits across different housing tenure options or within the same tenure option. It could also mean transition across different house types brought about by the changing life cycle of the household. Residential mobility decisions by households may be influenced by a range of factors. These factors may be endogenous or exogenous to the household. According to Rossi (1955), "push factors" account for reasons which pertain to the decision to move out of a former home, while those reasons pertaining to the choice among places to move to are considered as "pull factors". Push factors may include an increase in negative externalities like pollution or crime, changes in housing affordability (income dependent), 
dissatisfaction with current dwelling or changes in household structure (as a result of a birth or divorce for example). Pull factors often include things like access to good quality public service like schools and health care facilities, employment, leisure and recreational opportunities or the fulfilment of housing aspirations (Tim, David and Clive, 2018). Once the initial decision to move from a residence is made, it is followed by a series of interconnected decisions about tenure, house, neighbourhood type and location. According to Burgess and Skeltys (1992), it is difficult to understands these decisions in isolation from each other for a number of reasons. Some authors have opined that certain factors may influence a households' decision to move and these include: buildingspecific attributes, accessibility, social networks and community characteristics, quality and quantity of physical and social infrastructure like schools and parks, neighbourhood layout and features of the natural environment (Ghazali, Ngiam \& Mutum, 2020; Paaswell and Benjamin, 1977). It is also noteworthy to posit that residential location choices are in many ways a product of constraint as they often depend on the availability of a housing type, its location and when such unit(s) are supplied. Housing affordability, which is based on housing price and household income also influences households' mobility decisions alongside knowledge of alternative, societal expectation or norms and the regulatory environment. Hence, the urban housing milieu implies an area with diverse and spatially dispersed factors. These factors are said to attract and influence residential location decision of urban households.

Residential mobility has been widely researched in various fields including transportation, urban planning, housing policy, regional science, economics, sociology, and geography (Eluru, Sener. Bhat, Pendyala and Axhausen, 2009). Studies have continued to re-assess and re-conceptualize how contemporary life is configured by the movements of people, objects, capital and information (Cresswell and Clark, 2011). The growing interest in mobility which has been particularly prominent within population geography (Tyner, 2013), has now become very relevant in the field of urban real estate economics. Rossi (1955), who virtually pioneered research in residential mobility, described residential mobility as a means by which housing consumption patterns adjust over time. This position remains true today. However, the patterns of residential mobility and the household and personal dynamics that drive such mobility have undergone considerable transitions just like every aspect of human development. Residential mobility is associated with the human life cycle such as personal and family attributes as well as the residents' housing profile such as homeownership and housing type (Fatah, Salleh, Badarulzaman and Ali, 2015). Coupe and Morgan (2001) suggested that changes in household and personal characteristics are not the only factors that should be considered in household relocation studies. They noted that housing choices may be affected by residential history and market factors or forces that are external to the household. Thus, underscoring the importance of exogenous factors and their influence on household mobility decisions. Building further on this concept, Oh (2020) investigated the theory of residential mobility in terms of quality of life. With a focus on convenience and urban environment, satisfaction with transportation, commercial activities and cultural facilities affected mobility decisions for households in South Korea.

According to Ubani, Alaci \& Udoo (2017), the choice of residence generally involves trade-offs among several factors which gives the household the highest possible utility. Amongst these factors, cost and size of dwelling unit, and proximity to activity centre appear to be the most influential. Housing choice, whether current or proposed, was also found to be dependent on household demographics such as household size, life cycle and income.

A major theory underpinning residential mobility and how socio-economic considerations drive the spatial distribution of households within a metropolis is the Concentric Zone Theory developed by Ernest Burgess between 1925 and 1929. The model posited that an outward residential mobility from the city centre towards the suburban area was most likely as household income increases. Thus, changes in household income can trigger residential mobility in a spatially predictable manner within a metropolis. Although some limitations on the applicability of the model exist, it however laid the foundation for understanding how urban land is priced and how households respond to this by their housing location decisions.

\subsection{Social Drivers of Household Residential Mobility behaviour: Age, Family Ties and Race/Ethnicity}

Social factors play a significant role in influencing the residential mobility decisions of households. In terms of age and residential mobility behaviour, younger age groups are more likely to perform actual relocation following a period of mobility intentions compared to the elderly group. Younger people are more likely to be influenced by the need to have access to economic opportunities, transportation and entertainment hubs and as such will move more frequently in search of housing satisfaction (Jānis, Guido and Māris, 2018, Clark \& Huang, 2003). Hence, they represent a highly mobile segment of urban housing demand. This search for better economic opportunities sometimes creates chaos as younger urban dwellers are likely to have some difficulties matching their preferences and socioeconomic status with a residence and neighbourhood.

Race considerations influence residential mobility (Domenico, Daniel and Michael, 2019). Their study on the intrametropolitan mobility behaviour of whites in the suburban areas in America showed that racial considerations influenced mobility decisions as suburban whites who move tend to choose predominantly white communities. William (2000) addressed racial preferences in residential mobility decisions. $\mathrm{He}$ investigated if social class, family structure, and ingrouped racial preferences are enough to explain household sensitivity to neighbourhood racial composition. His findings 
suggested that social class differences, family structure differences, and in-group racial preferences alone were not enough to explain household residential racial preference and that household of all races practice racial avoidance behaviour. Ahmed (1992) conducted a research on migrant households in Karachi city. $\mathrm{He}$ found that ethnic considerations dominated the initial and subsequent mobility of the migrants. He adds that migrants to the city prefer to settle close to friends or relatives, or in areas where most households are of the same ethnic background. In another study, Maria and Reynolds (2002) demonstrated that African Americans overwhelmingly prefer 50-50 areas, a density far too high for most whites but their preferences were driven not by solidarity or neutral ethnocentrism but by fears of white hostility. That almost all blacks are willing to move into largely white areas if there is a visible black presence and white's preferences also play a key role, since whites are reluctant to move into neighbourhoods with more than a few African Americans. In the same vein, Ha and Weber (1991) noted that environmental safety, community/social factor, and housing quality factor are influential factors of residential mobility decision and satisfaction.

\subsection{Economic Drivers of Household Residential Mobility Behaviour: Employment and Income}

The role of employment in residential mobility decision of households has been contended. While some scholars posit that employment plays a prominent role in household residential mobility, others contend that the proximity of employment area to households' residency discourage residential mobility in metropolitan areas. $\mathrm{Wu}$ (2010) found that safety and proximity to the city, public transportation, workplace, sense of safety, medical and health facilities, and educational facilities influence households' residential mobility decision.

On the contrary, Kim, Horner and Marans (2005) espoused the importance of open space by demonstrating that those who decide to raise a family are more likely to trade accessibility to place of work for accessibility to more open space or a better quality of 'natural' environment. Thus, suggesting residential mobility is imminent when changes in household composition occurs. Also, the location and ease of transport accessibility to the workplace was highlighted as an important element in the selection of a residence as well as a decision to change residence. Shammi and Jannatul (2014) examined the factors influencing residential mobility choice of the garment workers of Dhaka city. The target group was the residents of Mirpur. The study revealed that house rent, availability of utility facilities and monthly household income amongst other variables were important factors influencing residential location decision. Clark and Withers (1999) demonstrated that in the United States, a job change at the local level exerted much influence on residential move than any other believed factor. They explained that a household that had made a job change turned out to be 24 times more likely to move than a household that did not make such changes. They also explained that homeowners are less likely to change residence in conjunction with a job change than renters. Waddell (1996) examined the choice of workplace as a determinant of residential location. He developed a nested logit model for worker's choice of workplace, residence, and housing tenure for the Dallas-Fort Worth metropolitan region. His results confirmed that accessibility to work in residential location was an important determinant of households' housing decision behaviour.

Household income can exert considerable influence on household residential mobility behaviour. Mulder \& Hooimeijer (1999) postulated that a critical factor for residential mobility decision is enough financial resource to support the moving costs and rent. It is relatively easier to perform an actual mobility when the available resource is stable (Helderman et al., 2004), as doing same with volatile income is irrational behaviour. An improvement in household income is likely to trigger mobility especially when the current dwelling unit has ceased to provide the expected utility. Thus, a household having a higher income margin is more likely to facilitate moving (De Groot, Mulder, Das et al., 2011). Lower income groups also more often state a wish to leave their neighbourhood (Van Ham \& Feijten, 2008), however, such wishes usually rarely translate to an actual move due to financial constraints. These scenarios underscore the centrality of income as a major influencer of households' residential mobility behaviour. Increase in household income, otherwise referred to as upward income mobility, is associated with an exit from low income areas (Vaalavuo, Ham and Kauppinen, 2017).

Changes in household income have also been linked to changes in household's life course. Although some scholars emphasize life course in different domains such as household size, employment level, and education level (Helderman et al., 2004), Rabe and Taylor (2010) grouped life course into income, employment, education, barriers to housing, health and disability, crime, living environment, retirement and unemployment stage. These predictors usually occur in people's life and not in the life events such as marriage and childbirth (Helderman et al., 2004). Therefore, the studies distinguish life cycle in the life course stage of age, income, household size, employment, education and more. Coulton \& Theodos (2012) in their work posit that many "push" and "pull" factors affect a household's decision to relocate, the place and timing. At the same time, however, the household may experience forces that make them resistant to a move, including attachment to their current house or neighbourhood and relationships that would be disrupted by a move; they may also face physical, economic, or social barriers to achieving a desirable living situation elsewhere. Such complexities have generated several complementary conceptual frameworks to explain both the intention to move and the actual movement. Coulton \& Theodos (2012) stated that a commonly used theoretical framework for understanding residential mobility is a disequilibrium model. 
A decision to move occurs when the current living arrangements become suboptimal. In the absence of such disequilibrium, the household will stay put, because it incurs adjustment costs and other losses when moving. What is optimal relates to the housing unit's characteristics, its location, and the neighbourhood surroundings relative to the household's needs and preferences however subject to cost and income constraints. Housing that may have been optimal can become suboptimal due to changes in household composition or circumstances, housing or neighbourhood quality, and household income or the cost of housing. Theory has also drawn a distinction among the household's experience of housing dissatisfaction, the intent to move, and the household's actual relocation (Speare, 1974). The decision about whether to move can be seen as weighing satisfaction with current housing relative to the anticipated satisfaction with alternatives. From this point of view, a combination of push and pull factors determines if, when, and where the household moves, subject to various constraints or barriers to mobility. Neighbourhood attachment and social ties may deter residential mobility or affect how far away a household moves from its current location. Positive feelings toward the neighbourhood and strong social connections have been found to keep households in place longer - changes in household income notwithstanding, and these effects have a stronger limiting effect on residential mobility among low-income compared with high-income families (Dawkins, 2006).

\section{METHODOLOGY}

This study is basically a descriptive research and the survey research design was adopted. A sample of 865 households was randomly drawn from the three municipalities which make up Enugu metropolis. Observation checklists were used to collect data on housing conditions while questionnaires were used to elicit responses from households on their demographic data and residential mobility behaviour. Descriptive statistics were used to summarize household demographic data and analyse household residential mobility behaviour.

\section{RESULTS AND DISCUSSION}

The demographic character of the study participants (Households), changes to the households' demographic character within the 10-year study period (2007 - 2017), households' housing optimization behaviour and households' residential mobility behaviour in response to changes in household income are presented and examined in this section.

\subsection{Demographic Character of Households $n$ Enugu Metropolis}

Table 1 shows that most of the respondents are male $(92.7 \%)$ while $7.3 \%$ are females. This distribution mirrors the sociocultural disposition of the study participants as household heads in the study area are predominantly male. However, exceptions exist where the females are heads of households when there are no male members in the household or where the males live in another location or are deceased. This has implications for housing consumption patterns in the study area in the sense that the presence of male household heads in an abstract sense brings some stability with respect to payment of rents as most property owners/managers are reluctant to let houses to female household heads. Again, the prevalence of male household heads enables adequate investigation of household residential mobility behaviour given the patriarchal nature of the study area. This is because new household formation -a major driver of residential mobility is mostly at the instance of the men.

Table 1: Demographic Character of Study Participants (Households) in Enugu

\begin{tabular}{|c|c|c|}
\hline \multicolumn{3}{|c|}{ Metropolis } \\
\hline $\begin{array}{l}\text { Gender } \\
\text { Male } \\
\text { female }\end{array}$ & $\begin{array}{c}\text { Frequency } \\
802 \\
63 \\
\end{array}$ & $\begin{array}{c}\text { Percentage } \\
92.7 \\
7.3 \\
\end{array}$ \\
\hline $\begin{array}{c}\text { Age } \\
\text { (Mean) } \\
\text { (Median) } \\
\text { (Mode) } \\
\text { (Minimum) } \\
\text { (Maximum) } \\
\text { (Standard Deviation) } \\
\end{array}$ & \multicolumn{2}{|c|}{$\begin{array}{c}46.52 \\
47 \\
54 \\
28 \\
78 \\
+9.91862 \\
\end{array}$} \\
\hline $\begin{array}{c}\text { Highest Educational } \\
\text { Qualification } \\
\text { PhD } \\
\text { MSc } \\
\text { BSc } \\
\text { HND } \\
\text { OND } \\
\text { SSCE } \\
\text { FSCL } \\
\text { OTHERS }\end{array}$ & $\begin{array}{c}\text { Frequency } \\
7 \\
11 \\
532 \\
163 \\
126 \\
20 \\
1 \\
5\end{array}$ & $\begin{array}{c}\text { Percentage } \\
.8 \\
1.3 \\
61.5 \\
18.8 \\
14.6 \\
2.3 \\
.1 \\
.6\end{array}$ \\
\hline $\begin{array}{c}\text { Employment Status } \\
\text { Civil Service } \\
\text { Organized Private Sector } \\
\text { Trader } \\
\text { Private Technician } \\
\end{array}$ & $\begin{array}{c}\text { Frequency } \\
563 \\
162 \\
101 \\
39 \\
\end{array}$ & $\begin{array}{c}\text { Percentage } \\
65.1 \\
18.7 \\
11.7 \\
4.5 \\
\end{array}$ \\
\hline $\begin{array}{c}\text { Duration of Current Employment } \\
<10 \text { Years } \\
10-20 \text { Years } \\
21-30 \text { Years } \\
>30 \text { Years } \\
\end{array}$ & $\begin{array}{c}\text { Frequency } \\
94 \\
493 \\
238 \\
40 \\
\end{array}$ & $\begin{array}{c}\text { Percentage } \\
10.9 \\
57.0 \\
27.5 \\
4.6 \\
\end{array}$ \\
\hline $\begin{array}{c}\text { Annual Household Income } \\
\text { (Mean) } \\
\text { (Median) } \\
\text { (Mode) } \\
\text { (Minimum) } \\
\text { (Maximum) } \\
\text { (Standard Deviation }\end{array}$ & \multicolumn{2}{|c|}{$\begin{array}{c}\$ 1,770,620.24 \\
¥ 1,265,440.00 \\
\# 1,920,000.00 \\
\$ 130,148.00 \\
\$ 7,531,705.00 \\
\pm 941769.26\end{array}$} \\
\hline $\begin{array}{c}\text { Household Income Contributors } \\
\text { Husband Only } \\
\text { Wife Only } \\
\text { Husband \& Wife } \\
\text { Husband, Wife \& Others } \\
\end{array}$ & $\begin{array}{c}\text { Frequency } \\
677 \\
31 \\
137 \\
20 \\
\end{array}$ & $\begin{array}{c}\text { Percentage } \\
78.3 \\
3.6 \\
15.8 \\
2.3 \\
\end{array}$ \\
\hline $\begin{array}{l}\text { Marital Status } \\
\text { Married } \\
\text { Single } \\
\text { Separated } \\
\text { Divorced } \\
\end{array}$ & $\begin{array}{c}\text { Frequency } \\
726 \\
87 \\
45 \\
7 \\
\end{array}$ & $\begin{array}{c}\text { Percentage } \\
83.9 \\
10.1 \\
5.2 \\
.8 \\
\end{array}$ \\
\hline $\begin{array}{c}\text { Household Size } \\
\text { (Mean) } \\
\text { (Median) } \\
\text { (Mode) } \\
\text { (Minimum) } \\
\text { (Maximum) } \\
\text { (Standard Deviation) }\end{array}$ & \multicolumn{2}{|c|}{$\begin{array}{c}5.52 \\
6 \\
7 \\
2 \\
9 \\
\pm 1.6215 \\
\end{array}$} \\
\hline
\end{tabular}

Source: Field Survey, 2019. 
The table above reveals that the mean age of the principal respondents is 46.52 years. From the same table, the modal age is 54 years while the median age is 47 years. These data suggest the age distribution of respondents is fairly a normal distribution. The minimum and maximum age from the distribution is 28 and 78 years respectively, while the Standard Deviation is \pm 9.91862 . Most of the study participants are in the mid-life stage of life and this corroborated the statistics from NPC and NBS on the age distribution of the population in the study area. Implicit in this age distribution is the fact that the current stage of life (midlife) of most of the respondents is characterized by some form of social stability in the sense of employment, financial independence socio-cultural balance. Since a minimum of one mandatory intra-city residential move in the last 12 years was part of the inclusion criteria for selecting study participants, the current mean age of the 46.52 years twelve years ago was 34 years and this represents an age bracket within which residential mobility was most likely. This may have been occasioned by new household formation, household babybooming period and/or job changes. These changes in household demographics have an influence on disposable income and by implication on household housing choices and residential mobility pattern.

An examination of the highest educational qualification of the study participants shows that most of the respondents (61.5\%) have a Bachelor's degree. This is followed by Higher National Diploma certificate holders (18.8\%). The table also shows that $0.8 \%$ of the study participants have a Doctorate degree while approximately $95 \%$ of the study participants have postsecondary school educational exposure and qualifications. Thus, it can be implied that their perception and appreciation of the phenomenon studied was rightly influenced by their level of education and exposure. Hence it is expected that the study participants behaved rationally in response to the housing market dynamics, especially as it pertains to residential rents and household income and how both may influence their mobility behaviour. The largely literate distribution of study participants confirms statistics on the educational character of the study area ( $81.2 \%$ literacy) which is above the national average (NBS, 2017). The fact that the study area is also an educational hub in the southeast with about 11 tertiary institutions domiciled within the state may also be contributory to ease of access to education at the postsecondary level.

Enugu is often referred to as a "civil service town". This is largely due its historic administrative role as the seat of government of the old eastern region. The survey of the employment status of the study participants shows that $65 \%$ of the study participants are employed in the civil servicefederal, state and local government. There are many federal ministries, departments and agencies in the study area. The same applies to the state government civil service. Again, Enugu metropolis spans across three local government areas Enugu North, Enugu South and Enugu East. Staff of these local government areas also reside within the metropolis. This explains why the metropolis is largely populated by residents working in the civil service. Respondents working in the organized private sector (OPS) account for $18.7 \%$ of the distribution while $15.2 \%$ of the respondents are traders or privately operating technicians. The prevalence of civil servants amongst the study participants, which mirrors the economic base of the study area, has a strong influence on the estimation of household income - an integral variable in this study. This is because data on income estimates from the civil service is accessible and reliable. The same applies to the organized private sector (OPS) which accounts for $18.7 \%$ of the distribution. Consequently, a high level of precision was attained in estimating household income for $83 \%$ of the study participants.

Data on respondent's duration of current employment was also collected in order to examine the employment stability of the study participants and its likely influence on household residential mobility behaviour. The table shows that more than half of the respondents $(57 \%)$ have worked in their current employment for $10-20$ years. This is followed by those who have spent $21-30$ years accounting for $27.5 \%$ of the respondents while those who have worked for more than 30 years or less than 10 years were $4.6 \%$ and $10.9 \%$ of the distribution respectively. A high rate of employment stability can be implied from this distribution of respondents' duration of employment. This is typical of the civil service which accounts for $65 \%$ of the employment status of the study participants.

Estimates of household annual income was obtained through a synthesis of data from the respondent's income estimates elicited from the study questionnaire, the Salaries and Wages Commission estimates for the Federal Civil Service and State Civil Service, their profession, work place, duration of work life, and income averages from similar employment opportunities within the metropolis. The various salary scales for both the civil service and organized private sector was also obtained to serve as a benchmark for estimating household income in order to improve the level of precision given the centrality of household income estimate to the study. All income estimates presented are net of all tax obligation(s). The modal annual household income from the distribution is $\$ 1,920,000.00$, while the mean and median annual household income is $\$ 1,770,620.24$ and $\$ 1,265,440.00$ respectively. The least annual household income is $\$ 130,148.00$ while the highest is $\$ 7,531,705.00$. The distribution shows that although there are some households with very high annual income estimates, most of the study participants earn below \#2 million annually based on statistics from the measures of central tendency. The Standard Deviation of \pm 941769.26 is quite high and confirms the wide disparity in income amongst the study participants.

Household income estimates in this research included all the incomes earned by a household unit. The survey revealed that $78.3 \%$ and $3.5 \%$ of the households have a mono-income source provided by the husbands and wives respectively. 
$15.8 \%$ of the households in the distribution have dual-income sources as both husbands and wives are responsible for household expenditures - housing inclusive, while $2.3 \%$ of the households have more than two persons contributing to defray cost of access to housing amongst other household obligations. From the survey, more than $80 \%$ of the households have a single income provider. This mono income source may limit a household's ability to adapt to adverse income shocks as well as their ability to easily optimize their housing consumption.

Data on the marital status of the study participants shows that $83.9 \%$ are married, less than $1 \%$ divorced, $5.2 \%$ are separated while $10.1 \%$ are single. The marital status of the respondents has implications for the volume of disposable income available for housing expenditure as well as household mobility behaviour. Given the significantly larger proportion of married respondents, households may be sensitive to volatile rent reviews given other financial obligations on the rather fixed disposable income. This has the potential to affect residential mobility behaviour. It may not be the case if majority of the respondents were single. Hence demographic characteristics of urban dwellers may have a significant influence on how households respond to housing market pull and push pressures which ultimately determine their housing location choices.

Table 1 also reveals that the mean household size from the survey is 5.5 persons (five adults and a child). The median household size is 6 while the modal household size is 7 . The least household size is 2 persons while households with 9 persons represent the maximum number of household members. The closeness of the median and mode to the mean suggests a near perfectly normal distribution. Given the statistics from the measures of central tendency, and the standard occupancy ratio of 1.5 persons per room, it can be inferred that the three-bedroom flat is the most suitable accommodation for a typical household in the study area - although it may be inadequate in some instances. Household residential mobility pattern should indicate movement towards this house type.

\subsection{Changes in Demographic Character of Households in Enugu Metropolis}

Changes in the demographic character of households in the study area was also investigated. Household sizes are dynamic and either expand or contract depending on the family life cycle stage. These changes influence housing choices and household residential mobility behaviour. Table 2 shows the type of changes to that occurred amongst participating households. $83.8 \%$ of the households experienced positive changes (additions) to their household sizes while 16.2\% of the households witnessed reduction in household size during the study period. Increase in household size by 1 person accounted for $50.8 \%$ of the distribution for households which experienced a positive change in household size while $23.6 \%$ of the households in this category increased by 3 persons. Given the largely positive change in household size, mobility pattern from smaller housing units (tenements or 1 \& 2bedroom apartments) to 3-bedroom apartments appears probable. The table also shows the distribution of the average number of persons by which a household's size either expanded or contracted. Most of the households (51.2\%) reported an average change in size by 1 person during the study period, while $23.2 \%$ reported an average change by three persons. Changes in household size involving two and four persons accounted for $10.8 \%$ and $13.1 \%$ of the distribution respectively. The least reported change in household size was for households who reported changes involving 5 persons as evidenced by $1.7 \%$ of the distribution. Since more than $50 \%$ of the households reported a change in household size occasioned by an average of 1-person, residential mobility due to changes in household size may not be as pronounced as it would have been if majority reported higher numbers.

Table 2: Crosstabulation Showing Changes in Household Size of Study Participants

\begin{tabular}{|c|c|c|c|c|c|c|c|}
\hline & \multirow{2}{*}{ Type of Change } & \multicolumn{5}{|c|}{ Household Size Change } & \multirow{2}{*}{ Total } \\
\hline & & 1.00 & 2.00 & 3.00 & 4.00 & 5.00 & \\
\hline \multirow{4}{*}{ Positive } & Count & 368 & 76 & 171 & 100 & 10 & 725 \\
\hline & $\%$ within Type of Change & $50.8 \%$ & $10.5 \%$ & $23.6 \%$ & $13.8 \%$ & $1.4 \%$ & $100.0 \%$ \\
\hline & $\%$ within Household Size Change & $83.1 \%$ & $81.7 \%$ & $85.1 \%$ & $88.5 \%$ & $66.7 \%$ & $83.8 \%$ \\
\hline & $\%$ of Total & $42.5 \%$ & $8.8 \%$ & $19.8 \%$ & $11.6 \%$ & $1.2 \%$ & $83.8 \%$ \\
\hline \multirow{4}{*}{ Negative } & Count & 75 & 17 & 30 & 13 & 5 & 140 \\
\hline & $\%$ within Type of Change & $53.6 \%$ & $12.1 \%$ & $21.4 \%$ & $9.3 \%$ & $3.6 \%$ & $100.0 \%$ \\
\hline & $\%$ within Household Size Change & $16.9 \%$ & $18.3 \%$ & $14.9 \%$ & $11.5 \%$ & $33.3 \%$ & $16.2 \%$ \\
\hline & $\%$ of Total & $8.7 \%$ & $2.0 \%$ & $3.5 \%$ & $1.5 \%$ & $.6 \%$ & $16.2 \%$ \\
\hline \multirow{4}{*}{ Total } & Count & 443 & 93 & 201 & 113 & 15 & 865 \\
\hline & $\%$ within Type of Change & $51.2 \%$ & $10.8 \%$ & $23.2 \%$ & $13.1 \%$ & $1.7 \%$ & $100.0 \%$ \\
\hline & $\%$ within Household Size Change & $100.0 \%$ & $100.0 \%$ & $100.0 \%$ & $100.0 \%$ & $100.0 \%$ & $100.0 \%$ \\
\hline & $\%$ of Total & $51.2 \%$ & $10.8 \%$ & $23.2 \%$ & $13.1 \%$ & $1.7 \%$ & $100.0 \%$ \\
\hline
\end{tabular}

Source: Field Survey, 2019 
However, for the $23.2 \%$ of households whose size changed by an average of three persons, the number of persons appear significant enough to alter housing consumption pattern if household income permits. Conversely, space requirements and available disposable income for housing may have an inverse relationship thus precluding any chances of housing optimization resulting in residential mobility.

\begin{tabular}{|c|c|c|c|c|c|}
\hline \multicolumn{6}{|c|}{$\begin{array}{l}\text { Table 3: Crosstabulation Showing Changes in Household Income of Study } \\
\text { Participants }\end{array}$} \\
\hline \multicolumn{2}{|c|}{$\begin{array}{l}\text { Type of } \\
\text { Change }\end{array}$} & \multicolumn{3}{|c|}{$\begin{array}{l}\text { Percentage Change in Annual } \\
\text { Household Income Estimate }\end{array}$} & \multirow{2}{*}{ Total } \\
\hline & & $<20 \%$ & $\begin{array}{l}20- \\
40 \%\end{array}$ & $\begin{array}{l}41- \\
60 \%\end{array}$ & \\
\hline \multirow[b]{2}{*}{ Positive } & Count & 550 & 41 & 9 & 600 \\
\hline & $\begin{array}{l}\% \text { within } \\
\text { Percentage } \\
\text { Change }\end{array}$ & $91.7 \%$ & $6.8 \%$ & $1.5 \%$ & $100.0 \%$ \\
\hline \multirow[b]{2}{*}{ Negative } & Count & 246 & 15 & 4 & 265 \\
\hline & $\begin{array}{c}\% \text { within } \\
\text { Percentage } \\
\text { Change }\end{array}$ & $92.8 \%$ & $5.7 \%$ & $1.5 \%$ & $100.0 \%$ \\
\hline \multirow{2}{*}{ Total } & Count & 796 & 56 & 13 & 865 \\
\hline & $\%$ within & $92.0 \%$ & $6.5 \%$ & $1.5 \%$ & $100.0 \%$ \\
\hline
\end{tabular}

Source: Field Survey, 2019

Changes in household income were also investigated in this study. The crosstabulation presented in Table 3 is a descriptive examination of the relationship between the type of change in household income and the percentage change in household income. The highest frequencies for both positive and negative changes in household income were below $20 \%$ as evidenced by $91.7 \%$ and $92.8 \%$ for positive and negative changes respectively within the groups. Less than $10 \%$ within the groups (Positive change and Negative change) reported income changes ranging from $20-40 \%$. Implicit in this crosstabulation is the fact that the identical character of the changes in household income may dampen the influence of household income on household residential mobility behaviour. Moreover, less than a $20 \%$ increase in household income may not realistically induce or support a drastic change in household's housing choice though a change may be desired.

\subsection{Households' Housing consumption pattern in Enugu Metropolis}

Data on households' housing consumption was collected in order to examine the pattern of residential mobility amongst the households. In the light of this, tables 4 and 5 below presents the previous and current house type of the households. Table 4 shows that $88.8 \%$ of the households occupied flats while $8.8 \%$ and $2.4 \%$ of the households previously occupied tenements and bungalows respectively.

Table 4: Frequency Distribution Showing Previous House Type Respondents

\begin{tabular}{|c|c|c|}
\hline House Type & Frequency & Percent \\
\hline Tenement & 76 & 8.8 \\
Flat & 768 & 88.8 \\
Bungalow & 21 & 2.4 \\
\hline TOTAL & 865 & 100.0 \\
\hline
\end{tabular}

Table 5 below shows an $8 \%$ rise in the number of households currently occupying flats amongst the examined households evidenced by $96 \%$ of the distribution. There is a $6.3 \%$ fall in the number of households occupying tenements currently while 11 and 2 households currently occupy bungalows and duplexes respectively.

Table 5: Frequency Distribution Showing Current House Type Respondents

\begin{tabular}{|c|c|c|}
\hline House Type & Frequency & Percent \\
\hline Tenement & 22 & 2.5 \\
Flat & 830 & 96.0 \\
Bungalow & 11 & 1.3 \\
Duplex & 2 & 0.2 \\
\hline TOTAL & 865 & 100.0 \\
\hline
\end{tabular}

Source: Field Survey, 2019

Implicit in these tables is a mobility pattern with respect to house type which is indicative of households attempting to optimize housing consumption. This corroborates the previous assumption of an increase in households requiring more space due to positive changes in the number of persons within a household. The surge in the percentage of households currently occupying 3-bedroom flats also underscores the prevalent mobility pattern.

\subsection{Household Income and Residential Mobility Behaviour in Enugu Metropolis}

In order to descriptively show how changes in household income may influence residential mobility behaviour, changes in housing type were matched with changes in household income.

\begin{tabular}{|c|c|c|c|c|c|c|}
\hline \multicolumn{6}{|c|}{ Table 6: Crosstabulation showing Change in Households' Income and } \\
Residential Mobility \\
\hline \multirow{2}{*}{$\Delta$ HHI* $^{*}$} & \multicolumn{2}{|c|}{ Current House Type (CHT) } & \multirow{2}{*}{ Total } \\
\cline { 2 - 6 } & $\begin{array}{c}\text { Tene } \\
\text { ment }\end{array}$ & Flat & $\begin{array}{c}\text { Bung } \\
\text { alow }\end{array}$ & $\begin{array}{c}\text { Dup } \\
\text { lex }\end{array}$ & \\
\hline \multirow{3}{*}{ Positive } & Count & 16 & 576 & 11 & 2 & 600 \\
\cline { 2 - 7 } & $\begin{array}{c}\% \text { within } \\
\text { CHT }\end{array}$ & $2.7 \%$ & $96.0 \%$ & $1.3 \%$ & $\begin{array}{c}0.2 \\
\%\end{array}$ & $\begin{array}{c}100.0 \\
\%\end{array}$ \\
\hline \multirow{3}{*}{ Negative } & Count & 6 & 254 & 0 & 0 & 265 \\
\cline { 2 - 7 } & $\begin{array}{c}\% \text { within } \\
\text { CHT }\end{array}$ & $2.3 \%$ & $95.8 \%$ & $0.0 \%$ & $\begin{array}{c}0.0 \\
\%\end{array}$ & $\begin{array}{c}100.0 \\
\%\end{array}$ \\
\hline \multirow{3}{*}{ Total } & Count & 22 & 830 & 11 & 2 & 865 \\
\cline { 2 - 7 } & $\%$ within & $2.5 \%$ & $96.0 \%$ & $1.3 \%$ & $\begin{array}{c}0.2 \\
\%\end{array}$ & $\begin{array}{c}100.0 \\
\%\end{array}$ \\
\hline
\end{tabular}

* $\Delta$ HHI: Change in Household Income

Source: Field Survey, 2019

Table 6 above provides descriptive statistics on the relationship between changes in household income and respondents' current house type. This relationship was examined to establish the influence of changes in household income on households' housing choice over the ten-year period (2007 - 2017) of the study. Changes in household income, both positive and negative resulted in an $8 \%$ increase in households occupying flats. Implicit in this outcome is the

Source: Field Survey, 2019 
possibility of households both upscaling and downscaling their housing choices to reflect their current income level.

\section{CONCLUSION}

This research sought to descriptively explore if variations in household income induced household residential mobility within Enugu metropolis between 2007 and 2017. Expectedly, there were changes in the demographic character of households within the study period - household income inclusive. Changes in household income amongst study participants, though negligible for the majority, translated to an $8 \%$ increase in households' occupying flats than other house types within the housing market in Enugu metropolis. This prevalent residential mobility behaviour underscores the need for collaborative efforts between public and private developers to improve on the quantity and quality of this house type within the metropolis.

\section{REFERENCES}

[1] Ahmed (1992). Choice of Location and Mobility Behaviour of Migrant Households in a Third World City. Sage Journals 29(7), 1147 - 1157 https://doi.org/10.1080/00420989220081091

[2] Burgess and Skeltys (1992). Findings from the Housing and Location Choice Survey: an overview', eds. Housing and Urban Development Division and Department of Health Housing and Community Services. Australian Government Publishing Service

[3] Clark and Huang (2003). The Life Course and Residential Mobility in British Housing Markets. Environment and Planning A, 35 (2), 323-399.

[4] Clark and Withers (1999). Changing Jobs and Changing Houses: Mobility Outcomes of Employment Transitions. Journal of Regional Science, 39(4), 653-673

[5] Coulton, C., Theodos, B., \& Turner, M.A. (2012). Residential Mobility and Neighbourhood Change: Real Neighbourhoods under the Microscope. City Scape; Journal of Policy Development and Research, 14(3), 55-90.

[6] Coupe and Morgan (2001). Towards a fuller understanding of Residential Mobility: A case study of Northampton, England. Environment and Planning 13.

[7] Cresswell, J. W., \& Clark, V. L. P. (2011). Designing and Conducting Mixed Methods Research (2nd edition). Thousand Oaks: CA Sage.

[8] Dawkins, C. (2006). Are Social Networks the Ties that Bind Families to Neighbourhoods? Housing Studies, 21(6), 864-881.

[9] De Groot, M., Clara, H., Das, M., \& Manting, D. (2011). Life Events and the Gap between Intention to move and Actual Mobility. Environment and Planning A, 43 (1), 48.

[10] Domenico, P., Daniel, T. L., and Michael C. T. (2019). Remaking Metropolitan America? Residential Mobility and Racial Integration in the Suburbs. Socious: Sociological Research for a Dynamic World (5).

[11] Eluru, S., Bhat, P., \& Kay, W. A. (2009). Understanding Residential Motility: Joint Model of the Reason for Residential Relocation and Stay Duration. Transportation Research Record, 2133 (1), 64-74.

[12] Ha, M., \& Weber, M. J. (1991). Determinants of Residential Environmental Qualities and Satisfaction: Effects of Financing, Housing programs and Housing Regulations. Housing and Society.

[13] Hamizah, A. F., Abdul, G. S., Nurwati, B., and Kausar, A. (2015). Factors Affecting Residential Mobility among Households in Penang, Malaysia. Procedia - Social and Behavioural Sciences $170 ; 516-526$

[14] Helderman, A., Mulder, C., \& VanHam, M. (2004). The Changing Effect of Home Ownership on Residential Mobility in the Netherlands 1980-98. Housing Studies, (19)4, 601-616.
[15] Jānis, K., Guido, S., and Māris, B. (2018). Residential satisfaction and mobility behaviour among the young: insights from the postSoviet city of Riga. Belgeo; DOI: https://doi.org/10.4000/belgeo.28347

[16] Kim, T.K., Horner, M.W., and Marans, R.W. (2005). Life Cycle and Environmental Factors in Selecting Residential and Job Locations. Housing Studies, 20(3) 457-73

[17] Kelly, J. B., \& Lamb, M. E. (2003). Developmental issues in relocation cases involving young children: When, whether, and how? Journal of Family Psychology, 17, 193-205.

[18] Maria and Reynolds (2002). The residential Preference of Blacks: Do They Explain Persistent Segregation. Social Forces, 937 - 980.

[19] Mulder, C. H., \& Hommejjer (1999). Residential Relocations in Life Courses. In Wissen, L.G., \& Dykotra, P. (Eds), Population Issues, 159-186. Springer, Netherlands.

[20] (NBS, 2016). Annual Abstracts of Statistics.

[21] Oh, Jooseok. (2020). Residential Mobility and Quality of Life between Metropolitan Areas: The Case of South Korea. Sustainability 12, 8611: doi:10.3390/su12208611

[22] Paaswell, R., \& Benjamin, J. (1977). A user-oriented housing choice model. Urban Systems, 2, 133-42.

[23] Rabe, B., \& Taylor, M. (2010). Residential Mobility, Quality of Neighbourhood and Life Course Events. Journal of Royal Statistical Society Series A, 173(3), 531-555.

[24] Rossi, P. H. (1955). Why Families Move: A Study in the Social Psychology of Urban Residential Mobility. Glencoe, Illinois: The Free Press.

[25] Shammi and Jannatul (2014). Study on The Factors Influencing Residential Location Choice of The Garments Workers of Mirpur, Dhaka City. International Journal of Chemical and Process Engineering, 1 (8): 73-86.

[26] Shawal, S. \& Ferdous, J. (2014). Study on the Factors Influencing Residential Location Choice of the Garments Workers of Mirpur, Dhaka City. International Journal of Chemical and Process Engineering Research, 1(6), pp.73-86.

[27] Speare, A. (1974). Residential Satisfaction as an Intervening Variable in Residential Mobility. Demography, 11, 173-188.

[28] Tim, M., David, M., and Clive, E. S. (2018). Residential Mobility: Towards progress in mobility health research. Progress in Human Geography 42(1) 112-133.

[29] Tyner, W. (2013). Biofuels and Land Use Charge Applying Recent Evidence to Model Estimates. Applied Sciences, 3, 14-38.

[30] Ubani, P., Alaci, D. S.A, and Udoo, V. (2017). Determinants of Residential Neighbourhood Choice in a Nigerian Metropolis. Journal of Humanities and Social Science 22 (7) 1- 11

[31] Van Ham M and Feijten P (2008) Who wants to leave the neighbourhood? The effect of being different from the neighbourhood population on wishes to move. Environment and Planning A 40(5): 1151-1170

[32] Viola Angelini \& Anne Laferrère, (2010). Residential Mobility of the European Elderly. CESifo Working Paper Series 3280, CESifo.

[33] Waddell, P. (1996). Accessibility and Residential Location: The Interaction of Workplace, Residential Mobility, Tenure, and Location Choices in Taxation, Resources and Economic Development Conference. Lincoln Land Institute.

[34] William, M. S. (2000). Influence of Race on Household Residential Utility. Geographical Analysis, 32 (3) 225 - 245.

[35] Wu (2010). Housing environment preference of young consumers in Guangzhou, China. Property Management. 28(3) 174-192.

[36] Vaalavuo, M., Maarten van Ham and Kauppinen, T. M. (2017). Income Increase and Moving to a Better Neighbourhood: An Enquiry into Ethnic Differences in Finland. IZA Institute of Labour Economics Discussion Paper Series (IZA DP No. 11076) 